\title{
Pathomechanisms of Paclitaxel-Induced Peripheral Neuropathy
}

\author{
Ines Klein ${ }^{1,2}$ and Helmar C. Lehmann ${ }^{1,2, *}$ \\ 1 Department of Neurology, University Hospital of Cologne, 50937 Cologne, Germany; ines.muke@uk-koeln.de \\ 2 Center for Molecular Medicine Cologne (CMMC), University of Cologne, 50937 Cologne, Germany \\ * Correspondence: helmar.lehmann@uk-koeln.de; Tel.: +49-221-478-87091; Fax: +49-221-478-87309
}

Citation: Klein, I.; Lehmann, H.C. Pathomechanisms of PaclitaxelInduced Peripheral Neuropathy. Toxics 2021, 9, 229. https://doi.org/ $10.3390 /$ toxics 9100229

Academic Editors: Valentina Carozzi and Wolfgang Grisold

Received: 28 July 2021

Accepted: 16 September 2021

Published: 22 September 2021

Publisher's Note: MDPI stays neutral with regard to jurisdictional claims in published maps and institutional affiliations.

Copyright: (c) 2021 by the authors. Licensee MDPI, Basel, Switzerland. This article is an open access article distributed under the terms and conditions of the Creative Commons Attribution (CC BY) license (https:/ / creativecommons.org/licenses/by/ $4.0 /)$.

\begin{abstract}
Peripheral neuropathy is one of the most common side effects of chemotherapy, affecting up to $60 \%$ of all cancer patients receiving chemotherapy. Moreover, paclitaxel induces neuropathy in up to $97 \%$ of all gynecological and urological cancer patients. In cancer cells, paclitaxel induces cell death via microtubule stabilization interrupting cell mitosis. However, paclitaxel also affects cells of the central and peripheral nervous system. The main symptoms are pain and numbness in hands and feet due to paclitaxel accumulation in the dorsal root ganglia. This review describes in detail the pathomechanisms of paclitaxel in the peripheral nervous system. Symptoms occur due to a length-dependent axonal sensory neuropathy, where axons are symmetrically damaged and die back. Due to microtubule stabilization, axonal transport is disrupted, leading to ATP undersupply and oxidative stress. Moreover, mitochondria morphology is altered during paclitaxel treatment. A key player in pain sensation and axonal damage is the paclitaxel-induced inflammation in the spinal cord as well as the dorsal root ganglia. An increased expression of chemokines and cytokines such as IL-1 $\beta$, IL-8, and TNF- $\alpha$, but also CXCR4, RAGE, CXCL1, CXCL12, CX3CL1, and C3 promote glial activation and accumulation, and pain sensation. These findings are further elucidated in this review.
\end{abstract}

Keywords: paclitaxel; CIPN; paclitaxel-induced peripheral neuropathy; neurotoxicity; neuropathy; taxol

\section{Introduction}

Cancer patients who receive anticancer treatment develop peripheral neuropathy in up to $60 \%$ of cases [1-3]. Several cytotoxic agents such as epothilones (ixabepilone), platinum compounds (cisplatin, carboplatin, and oxaliplatin), proteasome inhibitors (bortezomib), taxanes (paclitaxel and docetaxel), vinca alkaloids (vincristine and vinblastine), and immunomodulatory drugs (thalidomide) are able to induce a peripheral neuropathy (CIPN) [4-7]. The occurrence of pain in hands and feet in a "glove and stocking" pattern is one of the most common dose-limiting factors in treatment [8,9]. Besides pain, CIPN presents with numbness, loss of vibration sense due to the affection of large caliber sensory neurons, as well as dysesthesia and cold and mechanical hypersensitivity, functions that are executed by small A $\delta$ - and C-fibers. It is anticipated that due to an overall increase of survival, the prevalence of CIPN will increase in the next decade [10].

Paclitaxel is an antineoplastic agent most used in ovarian, breast, and prostate cancer treatment. Symptoms such as pain and numbness in hands and feet are predominately sensory due to paclitaxel accumulation in the dorsal root ganglia (DRG). The DRGs mainly consist of sensory neuron cells and are highly susceptible to paclitaxel accumulation due to a more permeable blood-nerve barrier [11].

Paclitaxel induces axonal transport disruption via microtubule stabilization, changes in morphology and function of mitochondria, and inflammation. These pathological changes cause symmetrical damage of axons and nerve fiber loss.

With the occurrence of paclitaxel-induced peripheral neuropathy, the treatment schedule of patients usually needs to be altered-e.g., via dosage reduction or treatment stop-to prevent further progress of neuropathic symptoms. 
In the following section, we review the antineoplastic mechanism of action of paclitaxel and its interference with cells of the peripheral nervous system via alteration of microtubule dynamics, mitochondria changes, induction of oxidative stress, and inflammation.

\section{Paclitaxel}

Paclitaxel was first extracted and isolated from the bark of the Pacific yew tree (Taxus brevifolia) in 1971 [12]. It became more viable with semi-synthetical production from a paclitaxel precursor from the European yew tree's needles.

Currently, paclitaxel is one of the most used taxanes, besides other formulations such as docetaxel, cabazitaxel, and nab-paclitaxel. Taxanes are commonly used to treat ovarian, breast, small- and non-small-cell lung, prostate, stomach, esophageal, bladder, pancreas head and neck cancer, as well as Kaposi's sarcoma and melanoma [13-16].

Structurally paclitaxel is a diterpenoid pseudoalkaloid with a taxane ring as its nucleus $\left(\mathrm{C}_{47} \mathrm{H}_{51} \mathrm{NO}_{14}\right)$. Due to its hydrophobic properties, a vehicle must be used for proper administration. Usually, a 50/50 solution of dehydrated ethanol and a polyethoxylated castor oil, Kolliphor EL, is used [17,18]. Kolliphor EL, formerly known as Cremophor EL, can form micelles around paclitaxel and thus keep paclitaxel in solution. However, the Kolliphor EL solution has several disadvantages. For once, it can alter the disposition and pharmacokinetics of paclitaxel [19]. Further, it can induce acute hypersensitivity reactions with symptoms of dyspnea, flushing, rash, chest pain, tachycardia, hypotension, angioedema, and generalized urticaria [20]. To prevent these possible side effects, patients need to be pre-treated with antihistamines and corticoids [21]. Moreover, Kolliphor EL can have direct effects on the peripheral nervous system (PNS) as well. It is neurotoxic itself due to the induction of axonal swelling and degeneration of DRG neurons and vesicles [22].

There is another paclitaxel formulation, nanoparticle albumin-bound paclitaxel (nabpaclitaxel), which is commonly used. Like CreEL-paclitaxel, nab-paclitaxel mainly accumulates in neurofilament 200-positive large-caliber neurons and less in Isolectin B4-, or calcitonin gene-related peptide-positive small-caliber neurons. Sensory nerve conduction studies demonstrated altered sensory dysfunction between the two formulations. It indicates that different "carriers" may impact the severity of neuropathy induced by paclitaxel via different tissue uptake [23].

\section{Antineoplastic Mechanism of Paclitaxel}

Paclitaxel and other taxanes can impair the increased abnormal cell proliferation and mitosis rate of tumor cells. During mitosis, microtubules are essential players in the segregation process of chromosomes into the daughter cells [24]. Especially during the interphase, microtubules act as tracks for organelles and the nucleus [25].

Microtubules are formed by $\alpha$ - and $\beta$-tubulin heterodimers to act as intracellular dynamic cytoskeletal polymers. Their dynamic stems from the ability to polymerize and depolymerize. Polymerization can also be described as rapid growth, and depolymerization can be characterized as shrinkage [26]. Due to these properties, the cell can rapidly reorganize its cytoskeleton. Both $\alpha$ - and $\beta$-tubulin are bound to guanosine triphosphate (GTP).

GTP-bound tubulin units are incorporated at the microtubule ends during the polymerization. This process makes the microtubule grow and form a stabilizing cap. Afterward, GTP gets hydrolyzed into GDP. This hydrolyzation process releases energy and destabilizes the microtubules and the microtubules splay apart at the end $[25,27]$.

Paclitaxel is able to interact with $\beta$-tubulin, which interferes with the dynamic process [28]. Through small openings in the microtubule lattice, paclitaxel can enter and bind to $\beta$-tubulin $[29,30]$. This causes a strengthening between the tubulin subunit's lateral contacts [31]. Hence, the depolymerization is suppressed and the microtubules are stabilized (Figure 1). 


\section{Physiological}

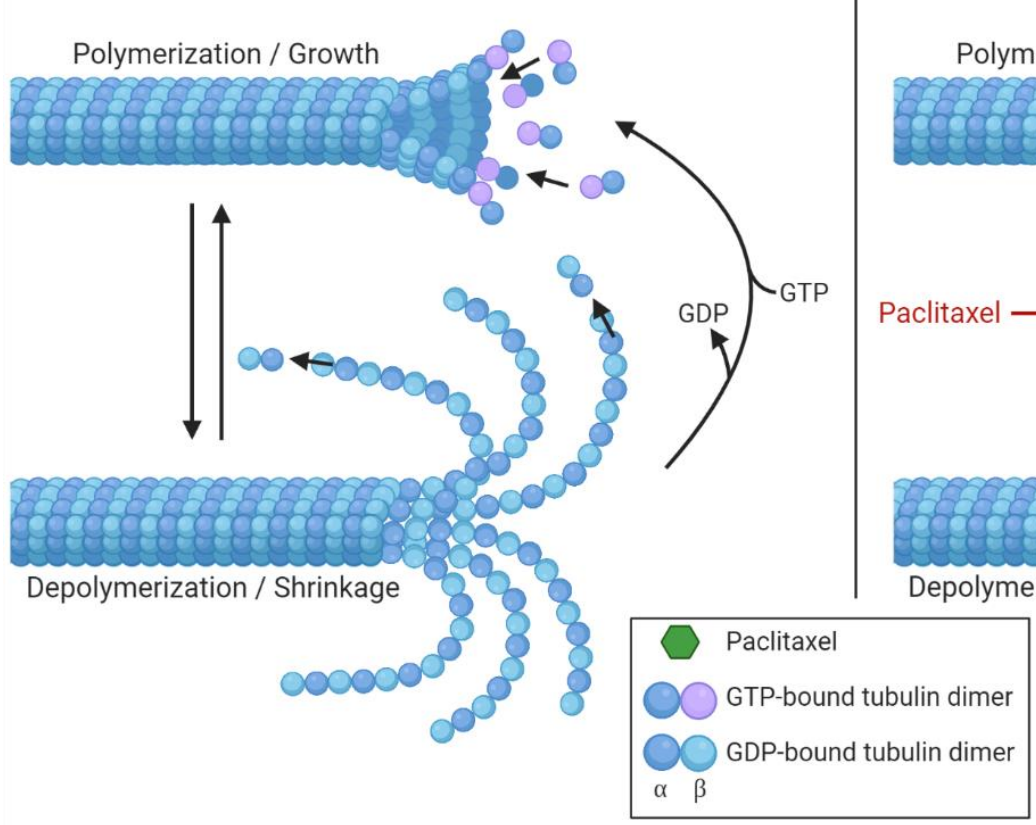

Pathological

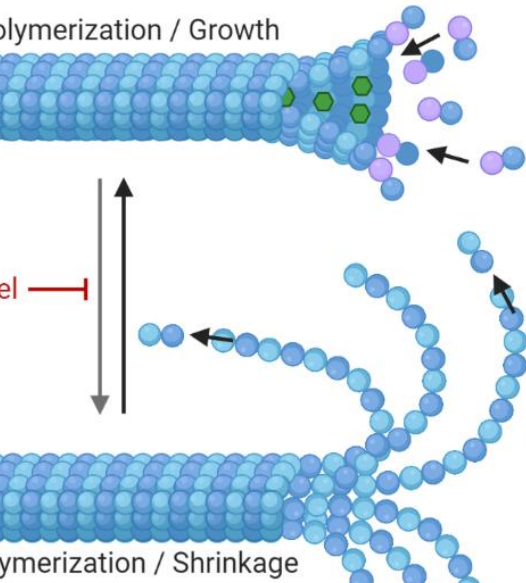

Figure 1. Paclitaxel enhances microtubule stability. Under physiological conditions, guanosine triphosphate (GTP)-bound tubulin dimers get incorporated at the growing end of the microtubules. This structure is supposed to form a stabilizing cap of GTP-bound tubulin. The conformation change in tubulin dimers is due to the GTP getting hydrolyzed into guanosine diphosphate (GDP), and this destabilizes the microtubule lattice. Through the loss of the GTP-tubulin cap, the microtubules are getting depolymerized. This process of microtubule depolymerization gets prevented by paclitaxel binding to $\beta$-tubulin (pathological condition). Created with BioRender.com (accessed on 20 September 2021).

Due to the interference with paclitaxel, mitosis is arrested between the metaphase and anaphase called the $\mathrm{G}_{2} / \mathrm{M}$ phase [17]. This leads to membrane potential reduction in mitochondria and causes the opening of the permeability transition pore channel. Proapoptotic factors release subsequently induces apoptosis [32]. Moreover, antiapoptotic effects are impaired, as paclitaxel is able to bind directly to B-cell lymphoma 2 (BCL2) [33].

\section{Paclitaxel-Induced Peripheral Neuropathy}

Paclitaxel-induced peripheral neuropathy is associated with a length-dependent axonal sensory neuropathy [34]. The induced neurotoxicity depends on paclitaxel dosage and infusion time and can be fostered by underlying conditions or co-treatment with other drugs $[35,36]$. This makes the severity and occurrence of paclitaxel-induced peripheral neuropathy hard to predict. First symptoms such as numbness, tingling, and/or allodynia in the patient's fingers and toes can be observed 24 to $72 \mathrm{~h}$ post-injection. Numbness and tingling can reach up to the lower leg and wrists of patients in a "glove and stocking" like manner $[37,38]$. These symptoms occur in up to $97 \%$ of all treated patients, especially when the cumulative dose exceeds $1400 \mathrm{mg} / \mathrm{m}^{2}[39,40]$. A total of $60 \%$ of all treated patients manifest chronic paclitaxel-induced peripheral neuropathy [40].

Due to the microtubule-stabilizing properties of paclitaxel, it damages peripheral axons symmetrically, and described symptoms are the phenotypic correlations of an axonal dying back pattern. In severe cases, axonal degeneration occurs along with secondary demyelination [41]. Axonal injury can be seen in nerve conduction studies by a reduction or a complete loss of sensory nerve action potentials [42]. Paclitaxel-induced impairment is most prominent in large myelinated A $\beta$-fibers [35,37]. This is reflected by symptoms such as the impaired sensation of vibration or touch. Further, a high concentration of paclitaxel leads to a loss of intraepidermal nerve fibers (IENFs). These nerve fibers enter the epidermis as $\mathrm{A} \delta$ - and C-fibers. Loss of those fibers is reflected in taxol-induced hyperalgesia and pain 
sensation in patients. In comparison, treatment with lower doses of paclitaxel induces an increase in IENFs diameter and a degeneration of terminal arbor [43]. This overall leads to a nerve fiber loss in the epidermis, manifesting in symptoms of thermal hyperalgesia and mechanical allodynia [44].

An important molecule that executes axonal degeneration is SARM1 (Sterile Alpha And TIR Motif Containing 1). It is activated in demyelinated axons and its NADase, which downstream can initiate the process of axonal self-destruction [45]. A class of isoquinoline small molecules has been described to reversible inhibit SARM1 NADase leading to protection against traumatic injuries and mitochondrial damage [46]. It has been recently described that these molecules were also able to prevent the loss of IENFs and partially protect axonal functions in a paclitaxel-induced peripheral neuropathy animal model [47].

\section{Mechanisms of Neuronal Injury and Neuronal Dysfunction}

\subsection{Altered Microtubules Dynamics}

Paclitaxel is a highly effective chemotherapeutic agent due to the stabilization of microtubules in cancer cells. However, this stabilization also does affect microtubules of sensory neurons in the DRG and axons of the PNS. Over the last decades, a number of in vitro and in vivo models for paclitaxel-induced neuropathy have been established (reviewed in $[48,49]$ ). There is evidence that paclitaxel impairs the transport of proteins, organelles, nutrients, neurotransmitters, and mRNA [50-54]. Downstream of impaired mitochondrial transport lay the undersupply of ATP, which is needed for axonal transport. This way, axonal transport is further decreased. Further, impaired mitochondrial transport promotes the breakdown of the ion gradient in the axolemma, which is crucial for electrochemical impulses $[55,56]$. Hence, microtubule stabilization leads to loss of axonal transport, which promotes axonal degeneration or axonopathy and ends in peripheral neuropathy [57]. Moreover, the impairment of axonal trafficking of RNA transport granules inhibits bclw translation, which reduces the expression of $\mathrm{Bcl} 2$ family member $\mathrm{Bclw}(\mathrm{Bcl} 212)$. The Bcl-2 homology (BH)4 domain of Bclw is able to bind inositol 1,4,5-trisphosphate receptor $\left(\mathrm{IP}_{3} \mathrm{R}\right) 1$. $\mathrm{IP}_{3} \mathrm{R}$ lays upstream of axonal degradation via the release of cytoplasmic calcium, leading to increased calcium flux into mitochondria and the proteolysis of calpain, a calcium-dependent enzyme [58]. Due to the impairment of axonal trafficking during paclitaxel treatment, $\mathrm{IP}_{3} \mathrm{R}$ is not bound and able to induce axonal degeneration [59].

\subsection{Mitochondria and Oxidative Stress}

Paclitaxel treatment impairs not only the axonal transport of mitochondria but also their morphology and function. Mitochondria of myelinated fibers and unmyelinated Cfibers and paclitaxel treatment swell up and vacuolize with the fragmentation of cristae due to the opening of the mitochondrial permeability transition pore $[50,60,61]$. These changes correlate with the pain-like behavior in rats [60]. Furthermore, the paclitaxel-induced alterations in the permeability transition pore opening also cause changes in calcium flow. Calcium flow changes induce deficiencies in the mitochondrial respiratory chain, which leads to ATP deficits. These ATP deficits are detectable during paclitaxel-induced pain sensation and persist even after the peak of pain sensation [62]. It is thought that impairment of mitochondrial function moreover results in degeneration of terminal arbors and further fostering the generation of neuropathic pain [63].

Furthermore, the response to oxidative stress is impaired by paclitaxel treatment, further increasing the ATP deficit [64]. It was observed that co-treatment with antioxidants reduced mitochondrial dysfunction, intraepidermal nerve fiber loss, and pain $[65,66]$. Mitochondrial damage and reactive oxygen species (ROS) are closely dependent since mitochondrial damage cause the production of ROS, i.e., $\mathrm{H}_{2} \mathrm{O}_{2}$ formation. ROS, in turn, cause damage to the mitochondria, inducing DNA fragmentation and mitochondrial membrane potential loss [67]. Hence, ROS are crucial players in the oxidative stress reaction and are increasingly expressed after paclitaxel treatment [68]. Along with elevated ROS levels, manganese activity, copper-zinc SOD activity, and glutathione (GSH) peroxidase antioxidant 
enzyme activities are induced by paclitaxel [68]. Notably, Fidanboylu and colleagues could demonstrate that a non-specific ROS scavenger, N-tert-Butyl- $\alpha$-phenylnitrone (PBN), could prevent the development of paclitaxel-induced peripheral neuropathy [69]. In chronic myelogenous leukemia K562 cells, apoptosis was induced with the generation of ROS and GSH depletion. Taxol further caused the increase of activity of c-Jun NH2-terminal kinase (JNK) and p38, which are known mediators of the stress activation pathways [70].

There is also evidence that epidermal matrix-metalloproteinase 13 (MMP-13) promotes degeneration of unmyelinated nerve fibers following paclitaxel treatment. In zebrafishes that are exposed to paclitaxel, $\mathrm{H}_{2} \mathrm{O}_{2}$ reactive species are increased in basal keratinocytes, originating from damaged mitochondria. This upregulates MMP-13, which contributes to matrix degradation and degeneration of axons in the epidermis [71]. While MMP-13 inhibition did not alter mitochondrial damage, it was able to prevent axon degeneration [72]. In general, matrix-metalloproteinases (MMPs) are regulated by ROS: expression of MMP-2 has been increased in a breast cancer cell line after being exposed to a mitochondrial ROS inducer [73]. In prostate cancer cells, increased $\mathrm{H}_{2} \mathrm{O}_{2}$ upregulated MMP-3 expression by inhibiting the MMP-3 suppressor [74]. Moreover, MMP-3 has been linked to macrophage accumulation in the DRGs.

\subsection{Inflammation and Pain}

Paclitaxel induces inflammation by cytokine and chemokine release and infiltration of non-resident macrophages into the DRGs, and this inflammatory reaction results in neuropathic pain [75]. Most prevalent are increased interleukin-1 $\beta$ (IL-1 $\beta$ ), IL-8, and tumor necrosis factor $\alpha$ (TNF- $\alpha$ ) expression [76]. An anti-TNF- $\alpha$ agent or an IL-1 receptor agonist was able to prevent paclitaxel-induced pain [77]. The same goes for IL-8 and its receptors, inhibition of those reduced nociception as well as mechanical and cold hypersensitivity [78]

Chemokine receptors that are upregulated in the DRG after paclitaxel treatment are C-X-C chemokine receptor type 4 (CXCR4) and receptor for advanced glycation end products (RAGE). The increased expression of those receptors goes along with an increased macrophage accumulation in the sciatic nerve. Interestingly paclitaxel-induced allodynia could be prevented with CXCR4 and RAGE antagonists [79].

Further, chemokines $\mathrm{C}-\mathrm{X}-\mathrm{C}$ motif chemokine ligand 1 (CXCL1), C-X-C motif chemokine ligand 12 (CXCL12), and C-X3-C motif chemokine ligand 1 (CX3CL1) are reported to be involved in the immune reaction following paclitaxel exposure. On the one hand, inhibition of CXCL1 was able to reverse paclitaxel-induced mechanical allodynia [80]. On the other hand, CXCL1's receptor CXCR2 and PI3K $\gamma$ have been found to be upregulated after paclitaxel treatment and may contribute to mechanical hypersensitivity [81]. CXCL12 expression is increased after paclitaxel treatment and correlates with increased excitatory postsynaptic currents in the spinal dorsal horn neurons. CXCL12 could induce mechanical allodynia since inhibition of the CXCL12 signaling pathway improved paclitaxel-induced mechanical allodynia [82]. Lastly, paclitaxel induces an upregulated expression of CX3CL1 in spinal neurons. Inhibition of this chemokine was reported to reduce macrophage-neuron interactions [83]. CX3CL1 possibly lies downstream of transcriptional factor NF- $\mathrm{kB}$ activation and histone acetylation. At the same time, NF- $\mathrm{KB}$ itself is a key player in thermal hypersensitivity in paclitaxel-induced peripheral neuropathy [84].

As another part of the innate immune system, the complement system was linked via complement component 3 (C3) activation to paclitaxel-induced peripheral neuropathy. In vitro, paclitaxel enhanced $\mathrm{C} 3$ activation, and in vivo knock-out of $\mathrm{C} 3$ ameliorated paclitaxel-induced touch sensitivity and increased intradermal nerve fibers [82].

In recent years, cannabinoid receptors 1 (CB1) and 2 (CB2) were discovered to possibly play a role in the immune reaction, microglia activation, and pain sensation after paclitaxel treatment. Increased expression of CB2 alongside chemokine (C-C motif) ligand 2 (CCL2) and IL-6, IL-4, and IL-10 expression after paclitaxel treatment is associated with a dysregulation of microglia in the dorsal horn [85-87]. CB1 and CB2 agonists inhibited spinal glial activation and IL-1 $\beta$, IL-6, TNF- $\alpha$, and CCL2 up-regulation. Further, they also 
modulated spinal p38 MAPK and NF- $\mathrm{kB}$ activation [88-90]. These effects prevented cold and mechanical allodynia [89]. These effects almost mirror co-treatment with minocycline. In this case, cannabinoid receptor agonism could have analgesic effects and, in return, reduce paclitaxel-induced neuropathic pain [86,88].

Besides paclitaxel-induced microglial activation in the dorsal horn, an astrocyte activation, independent from microglia activation, in the spinal cord is detectable [91].

The main players of inflammation in the DRG are accumulated macrophages. Initially, an upregulation of MMP-3 after paclitaxel exposure is detected. MMP-3 can break down the extracellular matrix and attract macrophages. This is followed by an upregulation of CD163, a macrophage marker, and C11b, a monocyte and macrophage marker. CD11b is further implied in pathogen recognition, phagocytosis, and cell survival. The accumulated macrophages in the DRG express pro-inflammatory markers desensitizing primary sensory afferent resulting in neuronal and glial damage. It is most likely that altered neuronal and glial physiology disrupts spinal dorsal horn input and generates neuropathic pain [92-95]. Another macrophage attracting chemokine, monocyte chemoattractant protein 1 (MCP-1), is increasingly expressed in small nociceptive DRG neurons as well as spinal astrocytes of paclitaxel treated rats [96]. Increased MCP-1 expression leads to an upregulation of its cognate receptor, $\mathrm{C}-\mathrm{C}$ chemokine receptor type 2 (CCR2), in large and medium-sized myelinated neurons. While increased overexpression of CCR2 induced increased calcium spikes in CCR2-positive neurons, macrophage depletion prevented increased CCR2 expression and reversed intra-epidermal nerve fiber loss and mechanical hypersensitivity [75]. Moreover, activation of the Toll-like receptor 4 (TLR4) could go hand in hand with increased MCP-1 expression [97,98].

The activation of spinal astrocytes and satellite glial cells (SGC) is thought to be a secondary response to macrophage activation and neuronal damage. Paclitaxel induced an activation state in SGC and Schwann cells detectable in an upregulation of the transcription factor 3 (ATF3) [91]. Further, paclitaxel treatment leads to increased gap junction coupling between the SGC, promoting ATP and neurotransmitter expression by the SGC. While SGC are essential players in neuronal homeostasis, increased ATP and neurotransmitter expression paradoxically could induce neuronal death [99]. Furthermore, the previously described increased expression of TLR4 could navigate TNF- $\alpha$ release of SGC and thus inflammation, pain sensation, and transient receptor potential (TRP) channel activation [68,100-102]. For example, TRPA1 and TRPV4 have already been implicated to be key roles in the induction of paclitaxel-induced cold hypersensitivity [103].

\subsection{Drug Transporters Involvement in Paclitaxel Translocation}

In the last few years, organic-anion-transporting polypeptides (i.e., OATP1B1 and OATP1B3) are increasingly recognized to be important molecules for translocation of paclitaxel across the plasma membrane. While hepatocytes are known to use OATPs to translocate paclitaxel, their expression and role in the peripheral nervous system are not well known. Recently, it has been shown that OATP1B2, the mouse homolog to OATP1B1 and OATP1B3, is expressed in mouse DRG and that pharmacological inhibition and knock-out of OATP1B2 ameliorated paclitaxel-induced peripheral neuropathy [104]. This indicated that OATP1B2 could be a driving force of paclitaxel accumulation in the DRG neurons. Moreover, OATP1B3 has been found to be expressed on ovarian and associated cancer cell lines [105], colorectal and pancreatic cancer cells [106], and castrationresistant prostate cancer cells [107]. OATP1B1 expression was confirmed on ovarian cancer cells [105].

Another candidate for paclitaxel transport across the cell membrane could be organic anion transporter 2 (OAT2). Interactions between OAT2 and paclitaxel have been observed [108], further underlined by increased accumulation of radiolabeled paclitaxel in OAT2 expressing oocytes [109]. However, OAT2 has three transcript variants and the corresponding variant has not been identified yet. OAT2 transcript variant 2 was able to translocate paclitaxel but is not expressed on the examined cell lines, while OAT2 tran- 
script variant 1 also had paclitaxel as its substrate in disregard on which cell type it is expressed [110].

Overall, it is crucial to understand the accumulation mechanism of paclitaxel in the sensory neuron, which could be achieved with further studies of drug transporters. Understanding and manipulating the transport process could prevent or ameliorate paclitaxelinduced peripheral neuropathy.

\section{Summary}

Paclitaxel is a potent antineoplastic agent that in tumor cells induces cell death via microtubule stabilization. However, it can cause chemotherapy-induced peripheral neuropathy in up to $97 \%$ of all treated patients. Typically, paclitaxel induces a length-dependent axonal sensory neuropathy correlating with the dose, infusion time, underlying conditions, and co-treatment with other drugs. Most prevalent are the symptoms of numbness and tingling in the feet and hands of the patients. While it acts as a microtubule-stabilizing and apoptosis-inducing agent in cancer cells, these properties can symmetrically damage peripheral axons and induce an axonal dying back pattern, mainly affecting A $\beta$-fibers. The microtubule stabilization impairs the transport of proteins, organelles, nutrients, neurotransmitters, and mRNA in the PNS. ATP undersupply and paclitaxel-induced morphological changes of mitochondria correlate with increased pain sensation. Typical inflammation markers in the PNS after paclitaxel treatment are IL-1 $\beta$, IL-8, and TNF- $\alpha$, which are thought to elicit pain sensation. Other markers involved in the immune response include CXCR4, RAGE, CXCL1, CXCL12, CX3CL1, and C3 (Figure 2). Interestingly, cannabinoid receptor agonists could ameliorate paclitaxel-induced neuropathic pain through the involvement in the immune reaction. Microglia and astrocytes independent from each other mainly get activated in the spinal cord (Figure 3). At the same time, SGC are the glial cells activated in the PNS, which in return can increasingly express TNF- $\alpha$ and neurotransmitters promoting neuronal death. Moreover, CD11b and CD163 positive macrophages infiltrate the DRG attracted by MMP-3 and MCP-1, which further can induce neuronal degeneration.

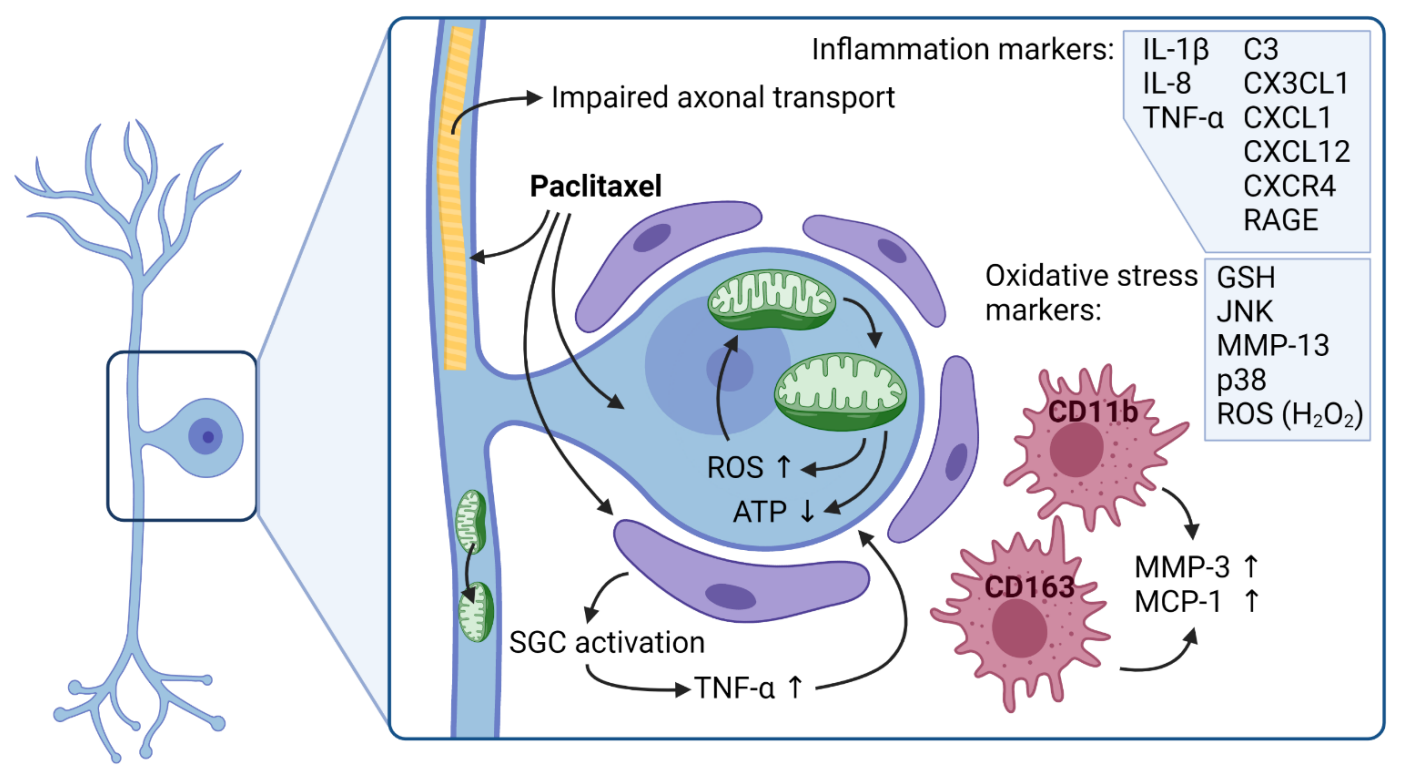

Figure 2. Pathomechanisms of paclitaxel-induced peripheral neuropathy in the peripheral nervous system. ATP-adenosine triphosphate, C3-complement component 3, CD11b—cluster of differentiation 11B, CD163-cluster of differentiation 163, CX3CL1-C-X3-C motif ligand 1, CXCL1-C-X-C motif chemokine ligand 1, CXCL12-C-X-C motif chemokine ligand 12, CXCR4 - as C-X-C chemokine receptor type 4, GSH-glutathione, IL-interleukin, JNK-c-Jun N-terminal kinase, MCP-1—monocyte chemoattractant protein 1, MMP—-matrix-metalloproteinase, RAGE-receptor for advanced glycation end products, ROS—reactive oxygen species, SGC—satellite glial cell, TNF- $\alpha$ - tumor necrosis factor; Created with BioRender.com (accessed on 20 September 2021). 


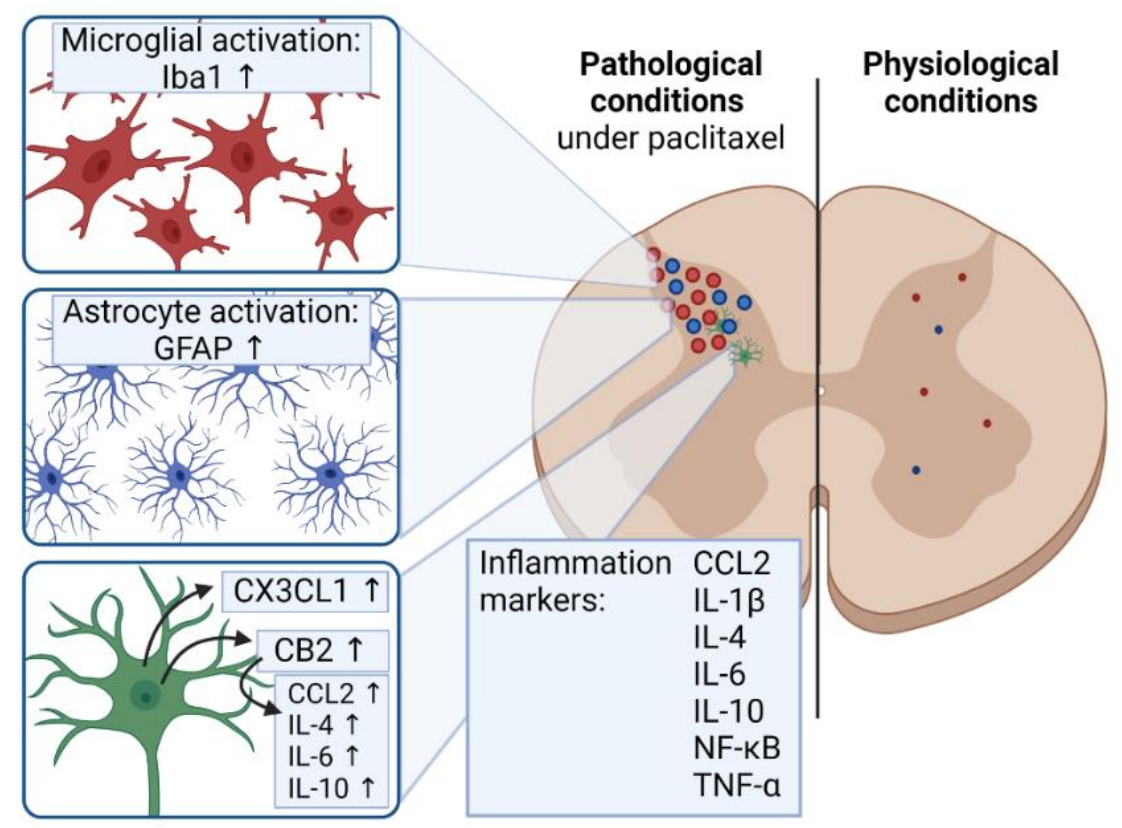

Figure 3. Pathomechanisms of paclitaxel-induced peripheral neuropathy in the spinal cord. CB2cannabinoid receptor type, CCL2-C-C motif ligand 2, CX3CL1-C-X3-C motif ligand 1, GFAP-glial fibrillary acidic protein, Iba1-ionized calcium-binding adapter molecule 1, IL-interleukin, NF- $\mathrm{kB}$ nuclear factor kappa B, TNF- $\alpha$-tumor necrosis factor; Created with BioRender.com (accessed on 20 September 2021).

Especially the immune response modulation in in vivo studies with rodents were able to ameliorate or prevent paclitaxel-induced peripheral neuropathy. However, with prolonged survival rates of cancer patients, paclitaxel-induced peripheral neuropathy becomes an increasingly larger problem. Still, thus far, no approaches are available that have reached clinical use to prevent or decrease neuropathy severity.

Author Contributions: I.K.: Conceptualization; Writing-Original Draft Preparation; WritingReview and Editing; Visualization. H.C.L.: Conceptualization; Writing—Review and Editing; Visualization; Supervision; Project Administration; Funding Acquisition. All authors have read and agreed to the published version of the manuscript.

Funding: This research received no external funding.

Institutional Review Board Statement: Not applicable.

Informed Consent Statement: Not applicable.

Data Availability Statement: Not applicable.

Conflicts of Interest: The authors declare no conflict of interest.

\section{References}

1. Mielke, S.; Sparreboom, A.; Mross, K. Peripheral neuropathy: A persisting challenge in paclitaxel-based regimes. Eur. J. Cancer 2006, 42, 24-30. [CrossRef]

2. Visovsky, C. Chemotherapy-Induced Peripheral Neuropathy. Cancer Investig. 2003, 21, 439-451. [CrossRef] [PubMed]

3. Lee, J.J.; Swain, S. Peripheral Neuropathy Induced by Microtubule-Stabilizing Agents. J. Clin. Oncol. 2006, 24, 1633-1642. [CrossRef] [PubMed]

4. Arrieta, O.; la Rosa, C.H.G.-D.; Aréchaga-Ocampo, E.; Villanueva-Rodríguez, G.; Cerón-Lizárraga, T.L.; Martínez-Barrera, L.; Vázquez-Manríquez, M.E.; Ríos-Trejo, M.; Álvarez-Avitia, M.; Hernández-Pedro, N.; et al. Randomized Phase II Trial of All-Trans-Retinoic Acid with Chemotherapy Based on Paclitaxel and Cisplatin as First-Line Treatment in Patients with Advanced Non-Small-Cell Lung Cancer. J. Clin. Oncol. 2010, 28, 3463-3471. [CrossRef] [PubMed] 
5. Corso, A.; Mangiacavalli, S.; Varettoni, M.; Pascutto, C.; Zappasodi, P.; Lazzarino, M. Bortezomib-induced peripheral neuropathy in multiple myeloma: A comparison between previously treated and untreated patients. Leuk. Res. 2010, 34, 471-474. [CrossRef] [PubMed]

6. Kanbayashi, Y.; Hosokawa, T.; Okamoto, K.; Konishi, H.; Otsuji, E.; Yoshikawa, T.; Takagi, T.; Taniwaki, M. Statistical identification of predictors for peripheral neuropathy associated with administration of bortezomib, taxanes, oxaliplatin or vincristine using ordered logistic regression analysis. Anti-Cancer Drugs 2010, 21, 877-881. [CrossRef]

7. Cavaletti, G.; Marmiroli, P. Chemotherapy-induced peripheral neurotoxicity. Curr. Opin. Neurol. 2015, 28, 500-507. [CrossRef]

8. Seretny, M.; Currie, G.L.; Sena, E.S.; Ramnarine, S.; Grant, R.; Macleod, M.R.; Colvin, L.; Fallon, M. Incidence, prevalence, and predictors of chemotherapy-induced peripheral neuropathy: A systematic review and meta-analysis. Pain 2014, 155, 2461-2470. [CrossRef]

9. Gutiérrez-Gutiérrez, G.; Sereno, M.; Miralles, A.; Casado-Sáenz, E.; Gutiérrez-Rivas, E. Chemotherapy-induced peripheral neuropathy: Clinical features, diagnosis, prevention and treatment strategies. Clin. Transl. Oncol. 2010, 12, 81-91. [CrossRef]

10. Alberti, P.; Lehmann, H.C. Chemotherapy induced peripheral neurotoxicity: Six essential articles for effective future research. Exp. Neurol. 2021, 337, 113555. [CrossRef]

11. Cavaletti, G.; Cavalletti, E.; Oggioni, N.; Sottani, C.; Minoia, C.; D’Incalci, M.; Zucchetti, M.; Marmiroli, P.; Tredici, G. Distribution of paclitaxel within the nervous system of the rat after repeated intravenous administration. NeuroToxicology 2000, 21, 389-393. [CrossRef]

12. Picard, M.; Castells, M.C. Re-visiting Hypersensitivity Reactions to Taxanes: A Comprehensive Review. Clin. Rev. Allergy Immunol. 2015, 49, 177-191. [CrossRef] [PubMed]

13. Kröger, N.; Achterrath, W.; Hegewisch-Becker, S.; Mross, K.; Zander, A. Current options in treatment of anthracycline-resistant breast cancer. Cancer Treat. Rev. 1999, 25, 279-291. [CrossRef] [PubMed]

14. Nathan, F.E.; Berd, D.; Sato, T.; Mastrangelo, M.J. Paclitaxel and tamoxifen. An active regimen for patients with metastatic melanoma. Cancer 2000, 88, 79-87. [CrossRef]

15. Belani, C.P. Paclitaxel and docetaxel combinations in non-small cell lung cancer. Chest 2000, 117, 144S-151S. [CrossRef]

16. Bunn, P.A., Jr.; Kelly, K. New combinations in the treatment of lung cancer: A time for optimism. Chest 2000, 117, 138S-143S. [CrossRef]

17. Jordan, M.A.; Toso, R.J.; Thrower, D.; Wilson, L. Mechanism of mitotic block and inhibition of cell proliferation by taxol at low concentrations. Proc. Natl. Acad. Sci. USA 1993, 90, 9552-9556. [CrossRef] [PubMed]

18. Dumontet, C.; Jordan, M.A. Microtubule-binding agents: A dynamic field of cancer therapeutics. Nat. Rev. Drug Discov. 2010, 9 , 790-803. [CrossRef] [PubMed]

19. Schiff, P.; Horwitz, S.B. Taxol assembles tubulin in the absence of exogenous guanosine $5^{\prime}$-triphosphate or microtubule-associated proteins. Biochemistry 1981, 20, 3247-3252. [CrossRef]

20. Gornstein, E.; Schwarz, T.L. The paradox of paclitaxel neurotoxicity: Mechanisms and unanswered questions. Neuropharmacology 2014, 76, 175-183. [CrossRef]

21. Nehate, C.; Jain, S.; Saneja, A.; Khare, V.; Alam, N.; Dubey, R.; Gupta, P. Paclitaxel Formulations: Challenges and Novel Delivery Options. Curr. Drug Deliv. 2014, 11, 666-686. [CrossRef]

22. Gelderblom, H.; Verweij, J.; Nooter, K.; Sparreboom, A. Cremophor EL: The drawbacks and advantages of vehicle selection for drug formulation. Eur. J. Cancer 2001, 37, 1590-1598. [CrossRef]

23. Klein, I.; Wiesen, M.H.J.; Albert, V.; Bobylev, I.; Joshi, A.R.; Müller, C.; Lehmann, H.C. Impact of drug formulations on kinetics and toxicity in a preclinical model of paclitaxel-induced neuropathy. J. Peripher. Nerv. Syst. 2021, 26, 216-226. [CrossRef]

24. Chandrasekaran, G.; Tatrai, P.; Gergely, F. Hitting the brakes: Targeting microtubule motors in cancer. Br. J. Cancer 2015, 113, 693-698. [CrossRef] [PubMed]

25. Burbank, K.S.; Mitchison, T.J. Microtubule dynamic instability. Curr. Biol. 2006, 16, R516-R517. [CrossRef]

26. Mitchison, T.J.; Kirschner, M.W. Dynamic instability of microtubule growth. Nature 1984, 312, 237-242. [CrossRef]

27. Nogales, E.; Wang, H.-W. Structural mechanisms underlying nucleotide-dependent self-assembly of tubulin and its relatives. Curr. Opin. Struct. Biol. 2006, 16, 221-229. [CrossRef]

28. Schiff, P.; Fant, J.; Horwitz, S.B. Promotion of microtubule assembly in vitro by taxol. Nature 1979, 277, 665-667. [CrossRef]

29. Nogales, E.; Wolf, S.G.; Khan, I.A.; Ludueña, R.F.; Downing, K.H. Structure of tubulin at $6.5 \AA$ and location of the taxol-binding site. Nature 1995, 375, 424-427. [CrossRef] [PubMed]

30. Risinger, A.L.; Riffle, S.M.; Lopus, M.; Jordan, M.A.; Wilson, L.; Mooberry, S.L. The taccalonolides and paclitaxel cause distinct effects on microtubule dynamics and aster formation. Mol. Cancer 2014, 13, 41. [CrossRef]

31. Prota, A.E.; Bargsten, K.; Zurwerra, D.; Field, J.J.; Díaz, J.F.; Altmann, K.-H.; Steinmetz, M.O. Molecular Mechanism of Action of Microtubule-Stabilizing Anticancer Agents. Science 2013, 339, 587-590. [CrossRef]

32. Bhalla, K.N. Microtubule-targeted anticancer agents and apoptosis. Oncogene 2003, 22, 9075-9086. [CrossRef] [PubMed]

33. McGrogan, B.T.; Gilmartin, B.; Carney, D.N.; McCann, A. Taxanes, microtubules and chemoresistant breast cancer. Biochim. et Biophys. Acta (BBA) Bioenerg. 2008, 1785, 96-132. [CrossRef] [PubMed]

34. Staff, N.P.; Grisold, A.; Grisold, W.; Windebank, A.J. Chemotherapy-induced peripheral neuropathy: A current review. Ann. Neurol. 2017, 81, 772-781. [CrossRef] [PubMed] 
35. Carlson, K.-S.; Ocean, A.J. Peripheral Neuropathy with Microtubule-Targeting Agents: Occurrence and Management Approach. Clin. Breast Cancer 2011, 11, 73-81. [CrossRef] [PubMed]

36. Jaggi, A.S.; Singh, N. Mechanisms in cancer-chemotherapeutic drugs-induced peripheral neuropathy. Toxicology 2012, 291, 1-9. [CrossRef]

37. Argyriou, A.A.; Koltzenburg, M.; Polychronopoulos, P.; Papapetropoulos, S.; Kalofonos, H. Peripheral nerve damage associated with administration of taxanes in patients with cancer. Crit. Rev. Oncol. 2008, 66, 218-228. [CrossRef] [PubMed]

38. Dougherty, P.M.; Cata, J.P.; Cordella, J.V.; Burton, A.; Weng, H.-R. Taxol-induced sensory disturbance is characterized by preferential impairment of myelinated fiber function in cancer patients. Pain 2004, 109, 132-142. [CrossRef] [PubMed]

39. Scripture, C.D.; Figg, W.D.; Sparreboom, A. Peripheral Neuropathy Induced by Paclitaxel: Recent Insights and Future Perspectives Curr. Neuropharmacol. 2006, 4, 165-172. [CrossRef]

40. Tanabe, Y.; Hashimoto, K.; Shimizu, C.; Hirakawa, A.; Harano, K.; Yunokawa, M.; Yonemori, K.; Katsumata, N.; Tamura, K.; Ando, M.; et al. Paclitaxel-induced peripheral neuropathy in patients receiving adjuvant chemotherapy for breast cancer. Int. J. Clin. Oncol. 2013, 18, 132-138. [CrossRef]

41. Woo, D.D.L.; Miao, S.Y.P.; Pelayo, J.C.; Woolf, A.S. Taxol inhibits progression of congenital polycystic kidney disease. Nature 1994, 368, 750-753. [CrossRef]

42. Windebank, A.J.; Grisold, W. Chemotherapy-induced neuropathy. J. Peripher. Nerv. Syst. 2008, 13, 27-46. [CrossRef]

43. Boyette-Davis, J.; Xin, W.; Zhang, H.; Dougherty, P.M. Intraepidermal nerve fiber loss corresponds to the development of Taxol-induced hyperalgesia and can be prevented by treatment with minocycline. Pain 2011, 152, 308-313. [CrossRef]

44. Ko, M.-H.; Hu, M.-E.; Hsieh, Y.-L.; Lan, C.-T.; Tseng, T.-J. Peptidergic intraepidermal nerve fibers in the skin contribute to the neuropathic pain in paclitaxel-induced peripheral neuropathy. Neuropeptides 2014, 48, 109-117. [CrossRef] [PubMed]

45. Gerdts, J.; Brace, E.J.; Sasaki, Y.; DiAntonio, A.; Milbrandt, J. SARM1 activation triggers axon degeneration locally via NAD+ destruction. Science 2015, 348, 453-457. [CrossRef]

46. Hughes, R.O.; Bosanac, T.; Mao, X.; Engber, T.M.; DiAntonio, A.; Milbrandt, J.; Devraj, R.; Krauss, R. Small Molecule SARM1 Inhibitors Recapitulate the SARM1 ${ }^{-/-}$Phenotype and Allow Recovery of a Metastable Pool of Axons Fated to Degenerate. Cell Rep. 2021, 34, 108588. [CrossRef]

47. Bosanac, T.; Hughes, R.O.; Engber, T.; Devraj, R.; Brearley, A.; Danker, K.; Young, K.; Kopatz, J.; Hermann, M.; Berthemy, A.; et al. Pharmacological SARM1 inhibition protects axon structure and function in paclitaxel-induced peripheral neuropathy. Brain 2021. [CrossRef]

48. Lehmann, H.C.; Staff, N.P.; Hoke, A. Modeling chemotherapy induced peripheral neuropathy (CIPN) in vitro: Prospects and limitations. Exp. Neurol. 2019, 326, 113140. [CrossRef]

49. Bruna, J.; Alberti, P.; Calls-Cobos, A.; Caillaud, M.; Damaj, M.I.; Navarro, X. Methods for in vivo studies in rodents of chemotherapy induced peripheral neuropathy. Exp. Neurol. 2019, 325, 113154. [CrossRef]

50. Flatters, S.J.L.; Bennett, G.J. Studies of peripheral sensory nerves in paclitaxel-induced painful peripheral neuropathy: Evidence for mitochondrial dysfunction. Pain 2006, 122, 245-257. [CrossRef]

51. Scuteri, A.; Nicolini, G.; Miloso, M.; Bossi, M.; Cavaletti, G.; Windebank, A.J.; Tredici, G. Paclitaxel toxicity in post-mitotic dorsal root ganglion (DRG) cells. Anticancer Res. 2006, 26, 1065-1070. [PubMed]

52. Benbow, S.J.; Wozniak, K.M.; Kulesh, B.; Savage, A.; Slusher, B.S.; Littlefield, B.A.; Jordan, M.A.; Wilson, L.; Feinstein, S.C. Microtubule-Targeting Agents Eribulin and Paclitaxel Differentially Affect Neuronal Cell Bodies in Chemotherapy-Induced Peripheral Neuropathy. Neurotox. Res. 2017, 32, 151-162. [CrossRef]

53. Tasnim, A.; Rammelkamp, Z.; Slusher, A.B.; Wozniak, K.; Slusher, B.S.; Farah, M.H. Paclitaxel causes degeneration of both central and peripheral axon branches of dorsal root ganglia in mice. BMC Neurosci. 2016, 17, 47. [CrossRef] [PubMed]

54. Bobylev, I.; Joshi, A.; Barham, M.; Ritter, C.; Neiss, W.F.; Höke, A.; Lehmann, H.C. Paclitaxel inhibits mRNA transport in axons. Neurobiol. Dis. 2015, 82, 321-331. [CrossRef]

55. Lin, M.T.; Beal, M.F. Mitochondrial dysfunction and oxidative stress in neurodegenerative diseases. Nature 2006, 443, 787-795. [CrossRef] [PubMed]

56. Navarro, A.; Boveris, A. The mitochondrial energy transduction system and the aging process. Am. J. Physiol. Physiol. 2007, 292, C670-C686. [CrossRef]

57. Fukuda, Y.; Li, Y.; Segal, R.A. A Mechanistic Understanding of Axon Degeneration in Chemotherapy-Induced Peripheral Neuropathy. Front. Neurosci. 2017, 11, 481. [CrossRef] [PubMed]

58. Krols, M.; Van Isterdael, G.; Asselbergh, B.; Kremer, A.; Lippens, S.; Timmerman, V.; Janssens, S. Mitochondria-associated membranes as hubs for neurodegeneration. Acta Neuropathol. 2016, 131, 505-523. [CrossRef]

59. Pease-Raissi, S.E.; Pazyra-Murphy, M.F.; Li, Y.; Wachter, F.; Fukuda, Y.; Fenstermacher, S.J.; Barclay, L.A.; Bird, G.H.; Walensky, L.D.; Segal, R.A. Paclitaxel Reduces Axonal Bclw to Initiate $\mathrm{IP}_{3}$ R1-Dependent Axon Degeneration. Neuron 2017, 96, 373-386.e6. [CrossRef]

60. Xiao, W.H.; Bennett, G.J. Effects of mitochondrial poisons on the neuropathic pain produced by the chemotherapeutic agents, paclitaxel and oxaliplatin. Pain 2012, 153, 704-709. [CrossRef]

61. Bernardi, P.; Krauskopf, A.; Basso, E.; Petronilli, V.; Blalchy-Dyson, E.; Di Lisa, F.; Forte, M.A. The mitochondrial permeability transition from in vitro artifact to disease target. FEBS J. 2006, 273, 2077-2099. [CrossRef] [PubMed] 
62. Duggett, N.; Griffiths, L.; Flatters, S.J.L. Paclitaxel-induced painful neuropathy is associated with changes in mitochondrial bioenergetics, glycolysis, and an energy deficit in dorsal root ganglia neurons. Pain 2017, 158, 1499-1508. [CrossRef]

63. Flatters, S.J.; Xiao, W.-H.; Bennett, G.J. Acetyl-l-carnitine prevents and reduces paclitaxel-induced painful peripheral neuropathy. Neurosci. Lett. 2006, 397, 219-223. [CrossRef]

64. Shim, H.S.; Bae, C.; Wang, J.; Lee, K.-H.; Hankerd, K.M.; Kim, H.K.; Chung, J.M.; La, J.-H. Peripheral and central oxidative stress in chemotherapy-induced neuropathic pain. Mol. Pain 2019, 15, 1744806919840098. [CrossRef] [PubMed]

65. Jin, H.W.; Flatters, S.J.L.; Xiao, W.H.; Mulhern, H.L.; Bennett, G.J. Prevention of paclitaxel-evoked painful peripheral neuropathy by acetyl-l-carnitine: Effects on axonal mitochondria, sensory nerve fiber terminal arbors, and cutaneous Langerhans cells. Exp. Neurol. 2008, 210, 229-237. [CrossRef]

66. Janes, K.; Doyle, T.; Bryant, L.; Esposito, E.; Cuzzocrea, S.; Ryerse, J.; Bennett, G.J.; Salvemini, D. Bioenergetic deficits in peripheral nerve sensory axons during chemotherapy-induced neuropathic pain resulting from peroxynitrite-mediated post-translational nitration of mitochondrial superoxide dismutase. Pain 2013, 154, 2432-2440. [CrossRef]

67. Yang, Y.; Karakhanova, S.; Hartwig, W.; D’Haese, J.G.; Philippov, P.P.; Werner, J.; Bazhin, A.V. Mitochondria and Mitochondrial ROS in Cancer: Novel Targets for Anticancer Therapy. J. Cell. Physiol. 2016, 231, 2570-2581. [CrossRef]

68. Duggett, N.A.; Griffiths, L.; McKenna, O.E.; de Santis, V.; Yongsanguanchai, N.; Mokori, E.B.; Flatters, S.J. Oxidative stress in the development, maintenance and resolution of paclitaxel-induced painful neuropathy. Neuroscience 2016, 333, 13-26. [CrossRef]

69. Fidanboylu, M.; Griffiths, L.; Flatters, S.J.L. Global Inhibition of Reactive Oxygen Species (ROS) Inhibits Paclitaxel-Induced Painful Peripheral Neuropathy. PLoS ONE 2011, 6, e25212. [CrossRef]

70. Meshkini, A.; Yazdanparast, R. Involvement of oxidative stress in taxol-induced apoptosis in chronic myelogenous leukemia K562 cells. Exp. Toxicol. Pathol. 2010, 64, 357-365. [CrossRef]

71. Cirrincione, A.; Pellegrini, A.D.; Dominy, J.R.; Benjamin, M.E.; Utkina-Sosunova, I.; Lotti, F.; Jergova, S.; Sagen, J.; Rieger, S. Paclitaxel-induced peripheral neuropathy is caused by epidermal ROS and mitochondrial damage through conserved MMP-13 activation. Sci. Rep. 2020, 10, 1-12. [CrossRef]

72. Lisse, T.S.; Middleton, L.J.; Pellegrini, A.D.; Martin, P.B.; Spaulding, E.L.; Lopes, O.; Brochu, E.A.; Carter, E.V.; Waldron, A.; Rieger, S. Paclitaxel-induced epithelial damage and ectopic MMP-13 expression promotes neurotoxicity in zebrafish. Proc. Natl. Acad. Sci. USA 2016, 113, E2189-E2198. [CrossRef] [PubMed]

73. Zhang, H.J.; Zhao, W.; Venkataraman, S.; Robbins, M.E.C.; Buettner, G.; Kregel, K.C.; Oberley, L.W. Activation of Matrix Metalloproteinase-2 by Overexpression of Manganese Superoxide Dismutase in Human Breast Cancer MCF-7 Cells Involves Reactive Oxygen Species. J. Biol. Chem. 2002, 277, 20919-20926. [CrossRef]

74. Hsieh, C.-L.; Liu, C.-M.; Chen, H.-A.; Yang, S.-T.; Shigemura, K.; Kitagawa, K.; Yamamichi, F.; Fujisawa, M.; Liu, Y.-R.; Lee, W.-H.; et al. Reactive oxygen species-mediated switching expression of MMP-3 in stromal fibroblasts and cancer cells during prostate cancer progression. Sci. Rep. 2017, 7, 1-14. [CrossRef]

75. Zhang, H.; Li, Y.; de Carvalho-Barbosa, M.; Kavelaars, A.; Heijnen, C.J.; Albrecht, P.J.; Dougherty, P.M. Dorsal Root Ganglion Infiltration by Macrophages Contributes to Paclitaxel Chemotherapy-Induced Peripheral Neuropathy. J. Pain 2016, 17, 775-786. [CrossRef]

76. Ji, R.-R.; Berta, T.; Nedergaard, M. Glia and pain: Is chronic pain a gliopathy? Pain 2013, 154, S10-S28. [CrossRef]

77. Al-Mazidi, S.; Alotaibi, M.; Nedjadi, T.; Chaudhary, A.; Alzoghaibi, M.; Djouhri, L. Blocking of cytokines signalling attenuates evoked and spontaneous neuropathic pain behaviours in the paclitaxel rat model of chemotherapy-induced neuropathy. Eur. J. Pain 2017, 22, 810-821. [CrossRef]

78. Laura, B.; Elisabetta, B.; Adelchi, R.P.; Roberto, R.; Loredana, C.; Andrea, A.; Michele, D.; Castelli, V.; Antonio, G.; Marcello, A.; et al. CXCR1/2 pathways in paclitaxel-induced neuropathic pain. Oncotarget 2017, 8, 23188-23201. [CrossRef]

79. Sekiguchi, F.; Domoto, R.; Nakashima, K.; Yamasoba, D.; Yamanishi, H.; Tsubota, M.; Wake, H.; Nishibori, M.; Kawabata, A. Paclitaxel-induced HMGB1 release from macrophages and its implication for peripheral neuropathy in mice: Evidence for a neuroimmune crosstalk. Neuropharmacology 2018, 141, 201-213. [CrossRef]

80. Li, D.; Huang, Z.-Z.; Ling, Y.-Z.; Wei, J.-Y.; Cui, Y.; Zhang, X.-Z.; Zhu, H.-Q.; Xin, W.-J. Up-regulation of CX3CL1 via Nuclear Factor-kB-dependent Histone Acetylation Is Involved in Paclitaxel-induced Peripheral Neuropathy. Anesthesiology 2015, 122, 1142-1151. [CrossRef]

81. Manjavachi, M.N.; Passos, G.F.; Trevisan, G.; Araújo, S.B.; Pontes, J.P.; Fernandes, E.S.; Costa, R.; Calixto, J.B. Spinal blockage of CXCL1 and its receptor CXCR2 inhibits paclitaxel-induced peripheral neuropathy in mice. Neuropharmacology 2019, 151, 136-143. [CrossRef] [PubMed]

82. Xu, J.; Zhang, L.; Xie, M.; Li, Y.; Huang, P.; Saunders, T.L.; Fox, D.A.; Rosenquist, R.; Lin, F. Role of Complement in a Rat Model of Paclitaxel-Induced Peripheral Neuropathy. J. Immunol. 2018, 200, 4094-4101. [CrossRef] [PubMed]

83. Montague, K.; Malcangio, M. The Therapeutic Potential of Monocyte/Macrophage Manipulation in the Treatment of Chemotherapy-Induced Painful Neuropathy. Front. Mol. Neurosci. 2017, 10, 397. [CrossRef] [PubMed]

84. Meng, J.; Zhang, Q.; Yang, C.; Xiao, L.; Xue, Z.; Zhu, J. Duloxetine, a Balanced Serotonin-Norepinephrine Reuptake Inhibitor, Improves Painful Chemotherapy-Induced Peripheral Neuropathy by Inhibiting Activation of p38 MAPK and NF-kB. Front. Pharmacol. 2019, 10, 365. [CrossRef] [PubMed]

85. Pevida, M.; Lastra, A.; Hidalgo, A.; Baamonde, A.; Menéndez, L. Spinal CCL2 and microglial activation are involved in paclitaxel-evoked cold hyperalgesia. Brain Res. Bull. 2013, 95, 21-27. [CrossRef] [PubMed] 
86. Wu, J.; Hocevar, M.; Bie, B.; Foss, J.F.; Naguib, M. Cannabinoid Type 2 Receptor System Modulates Paclitaxel-Induced Microglial Dysregulation and Central Sensitization in Rats. J. Pain 2019, 20, 501-514. [CrossRef]

87. Ha, J.-W.; You, M.-J.; Park, H.-S.; Kim, J.W.; Kwon, M.-S. Differential effect of LPS and paclitaxel on microglial functional phenotypes and circulating cytokines: The possible role of CX3CR1 and IL-4/10 in blocking persistent inflammation. Arch. Pharmacal Res. 2019, 42, 359-368. [CrossRef]

88. Burgos, E.; Gomez-Nicola, D.; Pascual, D.; Martín, M.I.; Nieto-Sampedro, M.; Goicoechea, C. Cannabinoid agonist WIN 55,212-2 prevents the development of paclitaxel-induced peripheral neuropathy in rats. Possible involvement of spinal glial cells. Eur. J. Pharmacol. 2012, 682, 62-72. [CrossRef]

89. Deng, L.; Guindon, J.; Cornett, B.L.; Makriyannis, A.; Mackie, K.; Hohmann, A.G. Chronic Cannabinoid Receptor 2 Activation Reverses Paclitaxel Neuropathy Without Tolerance or Cannabinoid Receptor 1-Dependent Withdrawal. Biol. Psychiatry 2015, 77, 475-487. [CrossRef]

90. Segat, G.C.; Manjavachi, M.N.; Matias, D.O.; Passos, G.F.; Freitas, C.S.; da Costa, R.; Calixto, J.B. Antiallodynic effect of $\beta$-caryophyllene on paclitaxel-induced peripheral neuropathy in mice. Neuropharmacology 2017, 125, 207-219. [CrossRef]

91. Peters, C.; Jimenez-Andrade, J.M.; Jonas, B.M.; Sevcik, M.A.; Koewler, N.J.; Ghilardi, J.R.; Wong, G.Y.; Mantyh, P.W. Intravenous paclitaxel administration in the rat induces a peripheral sensory neuropathy characterized by macrophage infiltration and injury to sensory neurons and their supporting cells. Exp. Neurol. 2007, 203, 42-54. [CrossRef] [PubMed]

92. Nishida, K.; Kuchiiwa, S.; Oiso, S.; Futagawa, T.; Masuda, S.; Takeda, Y.; Yamada, K. Up-regulation of matrix metalloproteinase-3 in the dorsal root ganglion of rats with paclitaxel-induced neuropathy. Cancer Sci. 2008, 99, 1618-1625. [CrossRef] [PubMed]

93. Villeneuve, D.J.; Hembruff, S.L.; Veitch, Z.; Cecchetto, M.; Dew, W.A.; Parissenti, A.M. cDNA microarray analysis of isogenic paclitaxel- and doxorubicin-resistant breast tumor cell lines reveals distinct drug-specific genetic signatures of resistance. Breast Cancer Res. Treat. 2005, 96, 17-39. [CrossRef] [PubMed]

94. Nair, V.; Arjuman, A.; Dorababu, P.; Gopalakrishna, H.N.; Rao, U.C.; Mohan, L. Effect of NR-ANX-C (a polyherbal formulation) on haloperidol induced catalepsy in albino mice. Indian J. Med. Res. 2007, 126, 480-484. [CrossRef]

95. Muthuraman, A.; Singh, N. Attenuating effect of hydroalcoholic extract of Acorus calamus in vincristine-induced painful neuropathy in rats. J. Nat. Med. 2011, 65, 480-487. [CrossRef]

96. Zhang, H.; Boyette-Davis, J.A.; Kosturakis, A.K.; Li, Y.; Yoon, S.-Y.; Walters, E.; Dougherty, P. Induction of Monocyte Chemoattractant Protein-1 (MCP-1) and Its Receptor CCR2 in Primary Sensory Neurons Contributes to Paclitaxel-Induced Peripheral Neuropathy. J. Pain 2013, 14, 1031-1044. [CrossRef]

97. Byrd-Leifer, C.A.; Block, E.F.; Takeda, K.; Akira, S.; Ding, A. The role of MyD88 and TLR4 in the LPS-mimetic activity of Taxol. Eur. J. Immunol. 2001, 31, 2448-2457. [CrossRef]

98. Li, Y.; Zhang, H.; Zhang, H.; Kosturakis, A.K.; Jawad, A.B.; Dougherty, P.M. Toll-Like Receptor 4 Signaling Contributes to Paclitaxel-Induced Peripheral Neuropathy. J. Pain 2014, 15, 712-725. [CrossRef]

99. Warwick, R.; Hanani, M. The contribution of satellite glial cells to chemotherapy-induced neuropathic pain. Eur. J. Pain 2013, 17, 571-580. [CrossRef]

100. Boehmerle, W.; Huehnchen, P.; Lee, S.L.L.; Harms, C.; Endres, M. TRPV4 inhibition prevents paclitaxel-induced neurotoxicity in preclinical models. Exp. Neurol. 2018, 306, 64-75. [CrossRef]

101. Materazzi, S.; Fusi, C.; Benemei, S.; Pedretti, P.; Patacchini, R.; Nilius, B.; Prenen, J.; Creminon, C.; Geppetti, P.; Nassini, R. TRPA 1 and $\mathrm{TRPV}_{4}$ mediate paclitaxel-induced peripheral neuropathy in mice via a glutathione-sensitive mechanism. Pflügers Arch. -Eur. J. Physiol. 2012, 463, 561-569. [CrossRef] [PubMed]

102. Wu, Z.; Wang, S.; Wu, I.; Mata, M.; Fink, D. Activation of TLR-4 to produce tumour necrosis factor- $\alpha$ in neuropathic pain caused by paclitaxel. Eur. J. Pain 2014, 19, 889-898. [CrossRef] [PubMed]

103. Alessandri-Haber, N.; Dina, O.A.; Yeh, J.J.; Parada, C.A.; Reichling, D.B.; Levine, J.D.; Baden, T.; Hedwig, B. Transient Receptor Potential Vanilloid 4 Is Essential in Chemotherapy-Induced Neuropathic Pain in the Rat. J. Neurosci. 2004, 24, 4444-4452. [CrossRef] [PubMed]

104. Leblanc, A.F.; Sprowl, J.; Alberti, P.; Chiorazzi, A.; Arnold, W.D.; Gibson, A.A.; Hong, K.W.; Pioso, M.S.; Chen, M.; Huang, K.M.; et al. OATP1B2 deficiency protects against paclitaxel-induced neurotoxicity. J. Clin. Investig. 2018, 128, 816-825. [CrossRef] [PubMed]

105. Svoboda, M.; Wlcek, K.; Taferner, B.; Hering, S.; Stieger, B.; Tong, D.; Zeillinger, R.; Thalhammer, T.; Jäger, W. Expression of organic anion-transporting polypeptides 1B1 and 1B3 in ovarian cancer cells: Relevance for paclitaxel transport. Biomed. Pharmacother. 2011, 65, 417-426. [CrossRef]

106. Abe, T.; Unno, M.; Onogawa, T.; Tokui, T.; Kondo, T.N.; Nakagomi, R.; Adachi, H.; Fujiwara, K.; Okabe, M.; Suzuki, T.; et al. LST-2, A human liver-specific organic anion transporter, determines methotrexate sensitivity in gastrointestinal cancers. Gastroenterology 2001, 120, 1689-1699. [CrossRef]

107. Wright, J.L.; Kwon, E.M.; Ostrander, E.; Montgomery, R.B.; Lin, D.W.; Vessella, R.; Stanford, J.L.; Mostaghel, E.A. Expression of SLCO Transport Genes in Castration-Resistant Prostate Cancer and Impact of Genetic Variation in SLCO1B3 and SLCO2B1 on Prostate Cancer Outcomes. Cancer Epidemiol. Biomark. Prev. 2011, 20, 619-627. [CrossRef]

108. Marada, V.V.; Flörl, S.; Kühne, A.; Müller, J.; Burckhardt, G.; Hagos, Y. Interaction of human organic anion transporter 2 (OAT2) and sodium taurocholate cotransporting polypeptide (NTCP) with antineoplastic drugs. Pharmacol. Res. 2015, 91, 78-87. [CrossRef] 
109. Cropp, C.D.; Komori, T.; Shima, J.E.; Urban, T.J.; Yee, S.W.; More, S.S.; Giacomini, K.M. Organic Anion Transporter 2 (SLC22A7) Is a Facilitative Transporter of cGMP. Mol. Pharmacol. 2008, 73, 1151-1158. [CrossRef]

110. Hotchkiss, A.G.; Berrigan, L.; Pelis, R.M. Organic anion transporter 2 transcript variant 1 shows broad ligand selectivity when expressed in multiple cell lines. Front. Pharmacol. 2015, 6, 216. [CrossRef] 